\title{
Ortaokul Türkçe Öğretmenlerinin Son 10 Yılda (2004-2014) Eğitim ve Dil Politikalarında Yaşanan Değişimlerin Türkçe Eğitimine Yansıması Hakkındaki Görüşleri
}

\author{
The Opinions of Upper-Primary School Turkish Language Teachers about the \\ Effects of Changes in Education and Language Policies in the Last Ten Years \\ (2004-2014) on Turkish Education
}

\begin{abstract}
Hasan KAVRUK* Mehmet ALVER

$\ddot{O}_{z}:$ Bu araştırmanın amacı Türkiye'de son 10 yılda (2004-2014) eğitim ve dil politikalarında yaşanan değişimlerin Türkçe eğitimine ne derecede yansıdığı konusunda Türkçe öğretmenlerinin görüşlerinden faydalanmaktır. Bu amaçla Giresun il merkezinde en az 10 yıllık kıdeme sahip 15 ortaokul Türkçe öğretmeniyle görüsşme yapılmıştır. Araştırmanın verileri yarı yapılandırılmış görüşme tekniği kullanılarak toplanmıştır. Araştırmada elde edilen veriler betimsel analiz tekniği kullanılarak çözümlenmiştir. Öğretmenler Türkiye'de eğitim ve dil politikalarının belirlenmesinde daha çok çağdaş yaklaşımların ele alındığını, eğitim ve dil politikalarını en çok siyasi değişimlerin etkilediğini, son 10 yılda eğitim ve dil politikalarında ciddi değişimlerin yaşandığını, okutmak istedikleri kitabı kendilerinin seçmesi gerektiğini, özel yayınevlerinin kitaplarından çok MEB'in kitaplarını tercih ettiklerini, Türkçenin doğru kullanılmadığı ve dilin yozlaştırıldığı görüşünü belirtmişlerdir. Dille ilgili yaşanan sorunların çözüme kavuşturulmasinda en önemli görevin ebeveynler ve öğretmenlere düştüğünü ifade etmişlerdir.
\end{abstract}

Anahtar sözcükler: Eğitim Politikası, Dil Politikası, Türkçe Eğitimi, Öğretmen Görüşleri

Abstract: The aim of this study is to reflect the opinions of Turkish language teachers about the impacts of changes in education and language policies in the last decade (2004-2014) on Turkish education. In order to do that, 15 Turkish language teachers who worked in Giresun city center and had at least 10 years teaching experience were interviewed. Semi-structured interview technique was used to gather the data. The data then was analysed by using descriptive analysis technique. The teachers thought that modern approaches had a big impact on determining education and language policies, political changes had determining role on education and language policies, significant changes on education and language policies had occured in the last decade, Turkish was not used properly and abused, teachers should choose the books which they wanted to use in their classes and they preferred the books published by MEB to the books published by private publishing houses, The teachers also stated that parents and teachers were the two most important stakeholders in order to find solutions to problems regarding Turkish languge.

Keywords: Education Policy, Language Policy, Turkish Education, Teachers’ Opinions

\footnotetext{
*Prof. Dr., İnönü Üniv., Eğitim Fakültesi, Sosyal Bilimler ve Türkçe Eğitimi Bölümü, Malatya. hasan.kavruk@inonu.edu.tr ***Yrd. Doç. Dr., Giresun Üniv., Eğitim Fak., Sosyal Bilimler ve Türkçe Eğitimi Bölümü, Giresun. mehmetalver2806@gmail.com

Bu çalışma, Prof. Dr. Hasan Kavruk danışmanlığında yürütülen ve Mehmet Alver tarafından hazırlanan doktora tezinden yararlanılarak üretilmiştir.
} 


\section{Giriş}

Bireylere toplumsal kültürün ve bilginin aktarılmasında eğitiminin önemi yadsınamaz bir gerçektir. Eğitim, kişileri hem yaşadığı toplumun hem de bu toplumun bağlı bulunduğu çağdaş dünyanın uyumlu bir üyesi hâline getirir. Ayrıca eğitim, kuralları anayasalarla belirlenmiş olan politik sisteme bağlı kuşaklar yetiştirmeyi de sağlar (Boran 2000, 303). Bireyi toplumun bilgi, değer ve davranış ilkelerine göre biçimlendirmeyi hedefleyen eğitim, toplumda ağırlıklı olan düşünce, yani toplumda egemen olan sınıfın dünyaya bakış açısı yani felsefesi doğrultusunda biçimlenir ve gelişir. Eğitim sistemi, ekonomik, politik ve toplumsal hedefleri her bireye mâl etmek, toplumu ve kişiyi bu hedefleri gerçekleştirecek nitelikte yetiştirmek üzere düzenlenmiştir. Bu nedenle ekonomik, politik ve toplumsal sistemlerin dayandığ nin aynı olması gerekir. Eğer eğitim sistemi, ekonomik, politik ve toplumsal hedeflerle çelişirse uzun süre varlığını koruyamaz (Kaygısız 1997, 5).

Toplumdaki bireyleri yetiştirerek onları topluma yararlı bireyler hâline getirmeyi temel amaç edinen eğitim kurumlarının toplumsal, politik, ekonomik ve bireyi geliştirme olmak üzere dört temel işlevi vardır. Tüm toplumlarda eğitim kurumları bu işlevleri yerine getirmek üzere ortaya çıkmıştır. Ancak bu işlevleri yerine getirme biçimi, hangi araçlar doğrultusunda gerçekleştirilebileceği ve hangi işlevin öncelikli olduğu toplumdan topluma değişiklik göstermektedir (Fidan \& Erden 1987, 63).

Eğitimin politik işlevi, toplumlarda devlet sisteminin ortaya çıkması ve eğitim kurumlarının millî bir nitelik kazanmasıyla önem taşımaya başlamıştır. Eğitimin politik işlevlerinden biri olan ulus bilinci oluşturma ve ulusal bütünlüğü sağlama bu açıdan önemli görülmüştür. Eğitim kurumları bireylere millî ideolojiyi, değerleri ve idealleri kazandırmaya çalışmaktadır. Onları mevcut politik düzene bağlı vatandaşlar olarak yetiştirmeyi hedeflemektedir. Devletin dayandığı temel felsefe, ideoloji ve ilkeler çeşitli ders ve faaliyetlerle çocuk ve gençlere kazandırılarak, eğitim kurumlarının mevcut politik düzenin korunmasına yardımcı olması sağlanmaktadır. Böylece her millet eğitim faaliyetlerini kendi politik rejiminin ideolojisi doğrultusunda düzenlemektedir (Fidan \& Erden 1987, 66).

Siyasi sisteme ekonomik, ideolojik ve politik girdiler sağlayarak devletin varlığının sürdürülmesinde eğitimin önemli katkısı bulunmaktadır. İdeoloji, toplumsal istek ve gereksinimleri karşılamak amaciyla üretilmekte ve bir toplumda yer alan sosyal, ekonomik, politik, kültürel gerçekliğin düşünsel boyutunu oluşturmaktadır. Bu nedenle tüm toplumlarda eğitimin içeriği ve amaçları devletin ideolojisi tarafindan belirlenmektedir (Gülbahar 2006, 1). Eğitim, devletin yönetim biçimine göre nitelik kazanır. Devlet eğitimden beklediklerini elde etmek için, ülke düzeyinde eğitim sistemini kurar ve işletir. Devletin eğitim sistemini kurmasının ve yönetmeyi üstlenmesinin başlıca dört amacı vardır: 1) Devlete bağl1, uyumlu yurttaşlar yetiştirmek, 2) Ülkeye gerekli insan gücünü yetiştirmek, 3) Eğitim yoluyla yurttaşları ulusun amaçlarına yönlendirmek, 4) Halkın eğitim gereksinimini karşılayarak eğitim hakkını vermek (Başaran 1999, 91-92).

Eğitim kurumları, iktidar ile birey arasında en önemli bağı oluşturmuşlardır. Eğitim kurumlarının bireyin yaşamındaki sosyalleşme sürecinin her aşamasında yer alması, iktidarın bireyin yaşamının her aşamasına nüfuz etmesini sağlamıştır (Sarı \& Önkal 2007, 47). Eğitim kurumlarının en kurumsallaşmış ve sistemlisi olan okullarda belli amaç ve ilkeler doğrultusunda politik düzenin istediği bireyler yetiştirilmiş ve yetiştirilmeye devam edilmektedir. Okulun amaçları, bir bakıma politikanın gereksinim ve beklentilerini kapsamaktadır. Bu açıdan bakıldığında gelecek kuşakları şekillendiren okul, politika için stratejik bir araç olarak görülmüştür (Varış et al. 1994, 170). 
Her ülke ve her politik düzen kendi varlığını sürdürmeye yönelik bir eğitim sistemi amaçlamıştır. Çünkü hiçbir siyasal sistem kendine düşman bireyler yetiştirmek istemez. Bu durum devleti ülkedeki eğitim hizmetlerini planlama ve denetlemeye sevk etmiştir. Günümüzde hemen bütün ülkelerde bilim ve eğitim, bir devlet politikası olarak ele alınmakta, eğitime ilişkin temel politikalar, yasalar, ilkeler, planlar, programlar, devlet ve hükümetler tarafindan düzenlenmekte ve uygulanmaktadır. Dolayısıyla devlet, eğitim kurumları üzerinde doğrudan bir kontrol yetkisine sahip olmaktadır (Şişman 2012, 107-109).

Günümüzde eğitim, bir kamu politikası olarak planlanıp uygulanmaktadır. Eğitim politikaları kısaca eğitim sistemi ve okulların yönetimiyle ilgili belirlenen ilke, yasa ve kurallar toplamıdır. Eğitim politikalarının belirlenip uygulanması ülkelerin siyasi sistemlerine göre merkezî hükümetler ya da yerel hükümetler veya yerel yönetimler tarafindan veya birlikte yürütülür. Ülkemizde merkezî düzeyde eğitim politikaları, TBMM ve hükümet tarafından belirlenir ve uygulanır (Şişman 2012, 107-114).

Eğitim politikaları; geçmişin izlerini taşır, bugünün gereksinimlerine yanıt verir, geleceğe yönelik algılamaları bünyesinde taşır, süreklilik ve planlama gerektirir. Bu nedenle, geçmişten dersler çıkarılması, bugünün sorunlarının iyi analiz edilerek tespit edilmesi ve gelecekte yaratacağ1 etkilerin öngörülmesi gerekir. Çünkü eğitim politikaları, bireysel ve toplumsal yaşantıları doğrudan etkiler (Yapıc1 2006).

Her siyasal ortamın benimsediği bir insan tipi ve bu insan tipini yetiştiren bir eğitim sistemini oluşturacak eğitim politikalarının olması söz konusudur. Modern toplumlarda, eğitim etkinliklerini ve eğitim politikalarını yöneltme, yönetme, uygulama, düzenleme ve saptama işlevlerini merkezî karar verme organı olan devlet yerine getirmiştir. $\mathrm{Bu}$ nedenle eğitimin kurumsallaşması ve eğitim politikaları da, devletin yapısına, tarihsel ve toplumsal konumlarına ve ekonomik sistemlerine bağlı olarak oluşmuş ve uygulamaya konulmuştur (Özdem 2007, 3 $10)$.

Ülkemizde eğitim politikalarının belirlenmesinde Devlet Planlama Teşkilatı (DPT), Millî Eğitim Bakanlığı (MEB), Yükseköğretim Kurulu (YÖK) gibi organlar yanında, siyasal partiler de önemli işlevler yüklenmiştir (Adem 1997, 52). Eğitim politikasını oluşturan temel ögeler ve yasal kaynaklar başta anayasa ve Atatürk ilkeleri olmak üzere eğitimle ilgili yasalar (1739 sayılı Millî Eğitim Temel Kanunu, 222 sayılı İlköğretim ve Eğitim Kanunu, 2547 sayılı Yükseköğretim Kanunu vb. gibi), kalkınma planları, Dünya Bankası ve uluslararası projeler ile planlar, ülkemizin üyesi bulunduğu uluslararası kuruluşların anayasaları, sözleşmeleri, Avrupa Birliğine uyum programları, hükümet programları ve millî eğitim şûra kararlarıdır (Alkan 1977, 31; Adem 1997, 53; Özdem 2007, 3; Memduhoğlu 2008, 2). Bu temel ögeler ve yasal kaynaklar dil politikalarının belirlenmesinde de önemlidir.

Dilin insanlar arasında anlaşmayı sağlayan bir araç olarak tanımlanması ona bireyselden çok, toplumsal bir anlam yüklemektedir. Toplumsal ilişkilerde bireyler arasındaki uzlaşının sağlanması, ulusların bir arada tutulması ve yönetiminde ise politika kavramı ön plana çıkmaktadır. $\mathrm{Bu}$ noktada dil ile politikayı birbiriyle ilişkilendiren kavram, dil politikasıdır (Durukan 2013, 1221). Dil politikası kısaca; bir siyasal birim içinde konuşulan dillere, bunların alan ve bölgelerine, gelişmelerine ve kullanımlarına ilişkin haklara yönelik ilke, karar ve uygulamalar bütünü olarak tanımlanabilir (Virtanen 2003, 18). Ulus devletlerin tarih sahnesine çıkması ile hayata geçen dil politikaları, resmî nitelik taşıyan ya da resmî olmasa da o denli etkili olabilen, birey ve kurumlar tarafından bilinçle yürütülen politikalardır. Dil politikaları, ulusçuluk akımı ile bağlant1lı olarak, o siyasal birimde ulusu şekillendiren dinamiklerle etkileşim içinde gelişmiştir. Dil politikalarını belirleyen etmenler arasında, söz konusu dillerin durumu, siyasal sistem ve resmî 
ideolojiler kadar uluslararası ilişkiler de bulunmaktadır. Dilin hem insan hayatı açısından hem de siyasal birimin etkin işlerliği açısından hayati önem taşıması, dünyanın çeşitli yerlerinde dil sorunlarını ele alınması zor, hassas konular içine itmektedir (Virtanen 2006, 148-149).

Toplumlarda çeşitli nedenlerle dil ve iletişim sorunları ortaya çıkmaktadır. Özellikle uluslaşma döneminde yaşanan büyük değişmeler sonucu ortaya çıkan dilsel gereksinimlerin karşılanması gerekmektedir. Dil ve iletişim sorunlarını çözmek, dilsel gereksinimleri karşılamak için de dil planlaması yapılmaktadır (İmer 2001, 1).

Kimi ülkelerde hükümetler, kimilerinde kişiler, kimi yerlerde akademiler, özel ya da resmî kuruluşlar dil planlaması konusunda karar verebilmektedir. Yönetimlere ve hükümetlere ek olarak dil planlamasında etkili olan başka etmenler de bulunmaktadır. Bunlar ulusal, ama hükümete bağlı olmayan kuruluşlar, ne ulusal ne de hükümete bağlı olan kuruluşlar, gazetelerdeki düzelti amaçlı okuma işlevi, yazarlar, yorumcular vb.'dir (İmer 2001, 12-14). Söz konusu kişi ve kurumlar devletlerin dil politikalarının oluşturulmasında veya uygulanan politikaların yaygınlaştırılmasında roller üstlenmektedirler (Durukan 2013, 1221). Devletler halkın konuştuğu dilleri; nüfuzlarını artırmak, meşruiyet kazanmak, katılımı teşvik etmek ya da kısıtlamak, millî bir kimlik oluşturmak ve bunu pekiştirmek ve gelir dağılımını belirlemek gibi amaçlarla etkilemeye çalışabilirler. İzlenen dil politikalarının devletin iç ve dış politikalarından etkilenmesi doğaldır (Virtanen 2003, 19). Devletler kamu hizmetinde mecburen dil tercihinde bulunmak zorunda oldukları için, bir dili düzenlemekten veya bireylerin kendi aralarında kullandığı dile müdahale etmekten kaçınabilmesi mümkün değildir. Bu dil de genellikle çoğunluğun dili olmuştur. Ulus inşa sürecinde izlenen politikaların anahtar rolünü oynayanlardan en etkilisi dil politikaları olmuştur. Dil planlaması üzerinden toplum planlaması yapılması da bu sebepledir (Açık 2013, 823).

Eğitim olgusunun birbiriyle etkileşimde bulunan üç temel ögesinin öğrenci, öğretmen ve program olduğu ifade edilmektedir. Eğitim sisteminin etkililiği ve verimliliği bu üç ögenin belirli bir hedefe doğru uyum içerisinde ilerlemesine bağlıdır. Eğitim sisteminin etkili şekilde işleyişini sağlamada ve öğrenci ile program ögesinin üzerinde etki sağlamada öğretmen ögesinin önemi yadsınamaz bir gerçektir (Üstüner 2004). Öğretmenlik mesleği toplumun sosyal, ekonomik, kültürel ve siyasal kalkınmasının temel kaynağı olarak görülmektedir. Etkili ve verimli bir eğitimin ancak nitelikli öğretmenler yetiştirmekle mümkün olacağı vurgulanmaktadır (Deringöl 2007, 17).

Toplumun eğitimden beklediği değerleri yerine getirmede en önemli faktör öğretmen faktörüdür (Azar 2011, 36). Öğretmenler sosyal ve/veya siyasal sistemi meşrulaştırıcı rolü nedeniyle uygarlık tarihini inşa eden en önemli sosyal kuvvetlerden biri olarak görülmüştür. Öğretmenler kendi toplumlarının toplumsal, kültürel, ulusal açıdan kimlik yapılandırıcıları, stratejik destek unsurları, toplumsal, kültürel miras taşıyıcıları ve bireyin sosyalleşmesini sağlayıc1 insan kaynăg 1 olagelmişler, bu nedenle toplumların maddi ve manevi mimarları olarak kabul edilmişlerdir (Özpolat 2005). Hedeflenen ve zamanla değişen eğitim ve dil politikalarının hayata geçirilmesinde öğretmenlerin büyük etkisi vardır. Bu nedenle araştırmada eğitim ve dil politikalarında yaşanan değişimlerin Türkçe eğitimine ne ölçüde yansıdığını, eğitim ve dil politikalarıyla ilgili sorunları ve önerileri öğretmenlerin görüşlerinden faydalanarak belirleyebilmek amaçlanmıştır. $\mathrm{Bu}$ amaçtan hareketle çalışmanın problem cümlesi "Ortaokul Türkçe ögretmenlerinin son 10 yılda (2004-2014) eğitim ve dil politikalarında yaşanan değişimlerin Türkçe eğitimine yansıması hakkındaki görüşleri nelerdir?" şeklinde belirlenmiştir.

$\mathrm{Bu}$ ana problem çerçevesinde ise araştırmada şu sorulara cevap aranmıştır: 
1. Türkiye'deki eğitim ve dil politikalarının belirlenmesinde daha çok hangi yaklaşımların ön plana alındığına ilişkin öğretmen görüşleri nelerdir?

2. Türkiye'de yaşanan siyasi, sosyal, ekonomik ve toplumsal değişimlerin eğitim ve dil politikaları üzerinde ne derece etkili olduğuna ilişkin öğretmen görüşleri nelerdir?

3. Yaşanan bu değişimlerden hangisinin eğitim ve dil politikaları üzerinde daha fazla etkili olduğuna ilişkin öğretmen görüşleri nelerdir?

4. Öğretmenlerin son 10 yılda eğitim ve dil politikalarında ciddi bir değişimin olup olmadığına ilişkin düşünceleri nelerdir?

5. Öğretmenlerin üniversitede aldıkları eğitimin şu anki Türkçe öğretim programının getirdiği yenilikleri uygulamalarına katkısının ne derecede olduğuna ilişkin öğretmen görüşleri nelerdir?

6. 10 yıl önceki ile şu anki Türkçe öğretimi ders materyalleri ve öğrenme ortamı arasında ne gibi farkların söz konusu olduğuna ilişkin öğretmen görüşleri nelerdir?

7. Ögretmenlerin derslerinde teknolojiden yeterince yararlanma durumu ile derslerinde teknolojiden yararlanmalarının öğrenciler üzerindeki olumlu ve olumsuz etkileri konusunda görüşleri nelerdir?

8. Önceki Türkçe öğretim programı (1981) ile şu anda uygulanan Türkçe öğretim programı arasındaki belirgin farklılıklara ilişkin öğretmen görüşleri nelerdir?

9. Önceki programa (1981) uygun hazırlanan ders kitapları ile şu anki programa uygun hazırlanan ders kitapları arasındaki farklılıklara ilişkin öğretmen görüşleri nelerdir?

10. Öğretmenlerin hem günlük hayatta hem de öğrencileriyle ilişkilerinde Türkçenin kullanımıyla ilgili yaşadıkları sorunlar ve bu sorunların çözüme kavuşturulabilmesi için neler yapılabileceğine ilişkin düşünleri nelerdir?

\section{Yöntem}

Araştırma nitel araştırma yöntem ve teknikleri kullanılarak yapılandırılmıştır. Nitel araştırmalar; gözlem, görüşme ve doküman analizi gibi veri toplama yöntemlerinin kullanıldığı, algıların ve olayların doğal ortamda gerçekçi ve bütüncül bir biçimde ortaya konmasına yönelik nitel bir sürecin izlendiği araştırmalar olarak tanımlanmaktadır (Yıldırım \& Şimşek 2006). Araştırmanın verileri niteliksel veri toplama tekniklerinden biri olan yarı yapılandırılmış görüşme tekniği kullanılarak toplanmıştır. Yarı yapılandırılmış görüşme tekniğinde, araştırmacı görüşme sorularını önceden hazırlar, ancak görüşme sırasında araştırmacı görüşme yapılan kişilere esneklik sağlamak için soruların yeniden düzenlenmesine ve başka konuların tartışılmasına izin verir (Ekiz 2003).

\section{Çalışma Grubu}

Türkiye'de son 10 yılda (2004-2014) eğitim ve dil politikalarında yaşanan değişimlerin Türkçe eğitimine ne derecede yansıdığını daha iyi anlayabilmek ve somut veriler ortaya koyabilmek amacıyla Giresun il merkezinde en az 10 yıllık kıdeme sahip 8 ortaokulda görev yapan 15 Türkçe öğretmeninin görüşlerinden faydalanılmıştır. Çalışma grubunu oluşturan öğretmenlerin 5'i kadın, 10'u erkektir.

Görüşme yapılmadan önce Giresun İl Millî Eğitim Müdürlügünden il merkezinde görevli ortaokul Türkçe öğretmenlerinin listesi alınmış ve bunlar içerisinden en az 10 yıllık kıdeme sahip ve 1981 ile 2006 programını uygulamış Türkçe öğretmenleri tesadüfi yolla seçilmiştir. Çalışma grubunu oluşturan öğretmenlerin 11'i Türkçe Eğitimi Bölümü mezunuyken; 4'ü Türk Dili ve Edebiyatı mezunudur. Araştırmaya katılan öğretmenler Ö1, Ö2, Ö3, ... Ö15 şeklinde kodlanmıştır. Araştırmaya katılan öğretmenlerin mezun oldukları bölüm ve mesleki kıdemleri ise şu şekildedir: 
Tablo 1. Öğretmenlerin Mezun Oldukları Bölüm ve Mesleki Kıdemleri

\begin{tabular}{llllll}
\hline Kod & Ö1 & Ö2 & Ö3 & Ö4 & Ö5 \\
Bölüm & Türkçe Eğitimi & Türkçe Eğitimi & Türkçe Eğitimi & Türk Dili Ed. & Türkçe Eğitimi \\
Kıdem & 10 yll & 11 yıl & 10 yll & 13 yll & 11 y1l \\
Kod & Ö6 & Ö7 & Ö8 & Ö9 & Ö10 \\
Bölüm & Türkçe Eğitimi & Türk Dili Ed. & Türkçe Eğitimi & Türkçe Eğitimi & Türkçe Eğitimi \\
Kıdem & 11 yll & 20 yıl & 11 yıl & 12 yll & 10 yll \\
Kod & Ö11 & Ö12 & Ö13 & Ö14 & Ö15 \\
Bölüm & Türkçe Eğitimi & Türkçe Eğitimi & Türk Dili Ed. & Türk Dili Ed. & Türkçe Eğitimi \\
Kıdem & 10 yll & 11 yll & 16 yıl & 15 yll & 11 yll \\
\hline
\end{tabular}

\section{Veri Toplama Teknikleri}

Veri toplama aracı olarak hazırlanan görüşme formu, ilgili literatür taranarak oluşturulmuş ve taslak görüşme formunun "kapsam geçerliği" ile ilgili olarak uzman görüşüne başvurulmuştur. Araştırmacı tarafından oluşturulan taslak, 3'ü Türkçe eğitimi, 1'i eğitim programları ve öğretimi, 1'i de ölçme-değerlendirme alanında uzman olmak üzere 5 öğretim üyesine sunulmuştur. Bu bağlamda uzmanlara formda yer alan her bir soruya ilişkin olarak "uygun", "uygun değil" ve "geliştirilmesi gerekir" seçeneklerini göz önünde bulundurarak değerlendirmeleri istenmiştir. Araştırmaya başlamadan önce görüşme formunda yer alan sorulardaki ifadelerin anlaşılıp anlaşılmadığını incelemek amacıyla çalışma gurubu dışında yer alan 3 öğretmenle ön uygulama yapılmış ve gerekli düzeltmeler yapıldıktan sonra görüşme formuna son hâli verilmiştir. Görüşme formunda 10 soru yer almıştır.

Görüşmeler araştırmacı tarafından 2013-2014 eğitim-öğretim yılının ikinci yarıyılında yüz yüze yapılmış ve her görüşme yaklaşı olarak 30 dakika sürmüştür. Görüşmeler ses kayıt cihazıyla kaydedildikten sonra yazılı hâle dönüştürülmüştür. Yazılı hâle getirilen metinler görüşmecilere gösterilerek kendi ifadeleriyle uyuşup uyuşmadığıyla ilgili görüş alınmış, böylece güvenirlik sağlanmaya çalışılmıştır. Görüşmeciler ifadelerin kendilerine ait olduğunu teyit etmişlerdir.

\section{Verilerin Analizi}

Görüşmeler sonunda elde edilen bulgular, betimsel analiz yöntemiyle çözümlenmiş ve alt problemler ölçüt alınarak maddeler hâlinde değerlendirilmiştir. Betimsel analiz, verilerin araştırma sorularının ortaya koyduğu temalara göre düzenlenmesine ve gözlem ve mülakat süreçlerinde kullanılan soruların dikkate alınarak sunulmasına imkân vermektedir (Yıldırım \& Şimşek 2006). Araştırmada öğretmen görüşlerinden bire bir alıntı yapılarak "geçerlik" sağlanmıştır. Çünkü görüşülen bireylerden doğrudan alıntılara yer vermek ve bunlardan yola çıkarak sonuçları açıklamak, "geçerlik" için önemli olmaktadır (Yıldırım \& Şimşek 2006).

\section{Bulgular ve Yorumlar}

Öğretmenlere sorulan sorulara verilen cevapların incelenip değerlendirilmesi sonucunda elde edilen bulgular şu şekildedir:

\section{Öğretmenlerin Türkiye'de Eğitim ve Dil Politikalarının Belirlenmesinde Hangi Yaklaşımların Ön Plana Alındığına Dair Görüşleri}

Öğretmenlere ülkemizde eğitim ve dil politikalarının belirlenmesinde daha çok hangi 
yaklaşımların (çağdaş mı, millî mi?) ele alındığı sorulmuştur. Öğretmen görüşleri tabloda gösterilmiştir:

Tablo 2. Eğitim ve Dil Politikalarının Belirlenmesinde Hangi Yaklaşımların (Çağdaş, Millî) Ön Plana Alındığına Dair Öğretmen Görüşleri

\begin{tabular}{ll}
\hline Çağdaş & Ö1-Ö3-Ö4-Ö5-Ö6-Ö7-Ö9-Ö10-Ö12-Ö13 \\
\hline Millî & Ö14-Ö15 \\
\hline Hem çağdaş hem millî & Ö2-Ö8-Ö11 \\
\hline
\end{tabular}

Öğretmenlerin büyük çoğunluğu (10 öğretmen) tarafından, eğitim ve dil politikalarının belirlenmesinde daha çok çağdaş yaklaşımların ele alındığı ifade edilmiştir:

"Millî değerlere, bizim eğitim ve dil politikalarında yeterince önem verilmediğini düşünüyorum. Adı gerçi millî eğitim ama ben millîlik sıfatının düştügünü düşünüyorum. Avrupa Birliğinin istekleri doğrultusunda çağdaş yaklaşımlarla güya politikalar oluşturulmaya çalışıllıyor (Ö1)”.

"Şu an millî değerlerden bence biraz uzaklaşılmış gibi duruyor. Çünkü baktı̆̆ımızda yeni eğitim ve ögretim politikasıyla beraber sürekli bir yenilenme, sürekli bir değişim, sürekli bir çağa ayak uydurma havası var. Daha çok teknoloji ve çağdaş yaklaşımlar ön planda tutuluyor diye düşünüyorum (Ö6)".

"Genelde çağdaş yaklaşımlar gibi görünüyor uygulamada. Millî değerlere değinilmeye çalı̧̧ılıyor fakat çok az açıkçası, millî değerlere ağırlık verildiğini düşünmüyorum (Ö12)".

"Millî değerlerin ön plana alındiğını düşünmüyorum. Çağdaş yaklaşımlar derken de yabancı ülkelerdeki olan konuşma tarzları veya tavır veya davranışların alındı̆̆ını düşünüyorum. Millî yaklaşımlar olsa bazı şeyleri ögretmemize hiç gerek bile kalmayacak (Ö13)".

Görüşme yapılan 2 öğretmen (Ö14, Ö15) millî değerlerin yaklaşım olarak esas alındığını, 3 öğretmen ise (Ö2, Ö8, Ö11) hem çağdaş hem de millî değerlerin esas alındığını ifade etmiştir.

"Bence son yillarda millî değerlere kayma söz konusu ama ikisinin ortak sentezi olmalı diye düşünüyorum (Ö14)".

"Hem millî değerlerin hem de çağdaş yaklaşımın da etkili olduğunu düşünüyorum (Ö8)".

\section{Eğitim ve Dil Politikalarının Belirlenmesinde Etkili Olan Ulusal ve Uluslararası Kurum ve} Kuruluşlar Hakkında Öğretmen Görüşleri

Öğretmenlere göre ülkemizde eğitim ve dil politikalarını en çok belirleyici olan ulusal kurumlar Millî Eğitim Bakanlığı ve Türk Dil Kurumu'dur. Bunun yanında hükümetin de belirleyici olduğu ifade edilmiştir. Uluslararası kurum ve kuruluşlar olarak ise eğitim ve dil politikalarını en çok etkileyen kurumların Avrupa Birliği olduğu ifade edilmiştir. ABD (Ö1, Ö12) ve İngiltere'nin (Ö8) de etkili olduğu söylenmiştir:

"Eğitim politikası deyince tabii ki bundaki en büyük sözcü hükümet, hükümette de bu eğitim işine Millî Eğitim Bakanlı̆̆ bakıyor malumunuz. Ben ulusal bir dil veya eğitim politikası olduğunu düşünmüyorum. Dediğim gibi bu yönetimi elinde bulunduran kişiler AB 'nin, ABD'nin ya da dış mihrakların güdümünde günübirlik politikalarını oluşturuyorlar 
(Ö1)".

"Tabii başta Millı̂ Eğitim Bakanlı̆̆ı. Uluslararası olarak yani uyum sürecinde Avrupa Birliğine yönelik çalışmalar etkili olmuştur (Ö4)".

"Başta Türk Dil Kurumunun dil politikaları üzerinde etkili olduğunu düşünüyorum. Daha sonra Bakanlı, Millî Ĕ̆itim Bakanlı̆̆l, daha sonra $A B$ ve özellikle ben Ingiltere'nin çok büyük etkisi olduğunu düşünüyorum. Biliyorsunuz dünya üzerinde dilini satarak para kazanan tek devlet, tek millet Ingiltere (Ö8)".

"Benim gözümde şu anda bir zamanlar Osmanlı Devleti nasıl cihan devleti olmuşsa dünyayı yönetmişse şu anda da benim gözümde ABD cihan devleti ve kendi politikaların her şekilde yönlendiriyor. Dolayısıyla bizim dil programlarımızın yanında eğitim programlarını da onların yönlendirdiğini düşünüyorum. Çünkü bizde devlet politikast yok, dil üzerine sadece hükümet politikası var. Hatta hükümetin de içerisinde bakanların kendi programları var. Çünkü bir hükümetin dahi bakanı geldiği zaman köklü değişimler yapıyor. Ondan sonraki gelen Bakan hepsini yıkı daha farklı bir sistem getirebiliyor. Bu da bizim ne kadar dengesiz ve tutarsız olduğumuzun göstergesi. Millı̂ konuda millî şuuru uyandırı da ona sahip olma hususunda ne kadar zaylf olduğumuzun bir göstergesi. Yani dış odakl kuvvetlerin maalesef tesiri ve etkisi altındayız kesinlikle (Ö12)".

\section{Öğretmenlerin Ülkemizde Yaşanan Siyasi, Sosyal, Ekonomik ve Toplumsal Değişimlerin Eğitim ve Dil Politikaları Üzerinde Etkisi Olup Olmadığına Dair Görüşleri}

Öğretmenlere ülkemizde yaşanan siyasi, sosyal, ekonomik ve toplumsal değişimlerin eğitim ve dil politikaları üzerinde etkisinin olup olmadığı sorulmuştur. Öğretmenlerin tümü eğitim ve dil politikaları üzerinde siyasi, sosyal, ekonomik ve toplumsal değişimlerin eğitim ve dil politikaları üzerinde etkisi olduğunu ifade etmişlerdir:

"Son derece etkili olmaktadır. Bence yani tüm değişimler siyaset değiştiği zaman hatta hükümetler değişmese de hükümetlerin içindeki anlayışlar değişstiği zaman eğitim politikalarının değişebildiğini son yıllarda gördük(Ö5)".

"Tabii ki etkili olmaktadır (Ö9)".

"Kesinlikle oluyor. Hem sosyal olarak hem teknolojik olarak hem de ekonomik olarak insanların, özellikle siyasetçilerin kullanmış oldukları üsluplar, halka yaklaşım şekli çok etkili oluyor. Bir siyasetçinin çıkıp söylemiş olduğu söz insanların ögretmenlere bakış açısını tamamıyla değiştiriyor (Ö12)".

Öğretmenlerin Ülkemizde Yaşanan Siyasi, Sosyal, Ekonomik ve Toplumsal Değişimlerden Hangisinin veya Hangilerinin Eğitim ve Dil Politikaları Üzerinde Daha Etkili Olduğuna İlişkin Görüşleri

Öğretmenlere siyasi, sosyal, ekonomik ve toplumsal değişimlerden hangisinin veya hangilerinin eğitim ve dil politikaları üzerinde daha etkili olduğu sorulmuştur. Öğretmenlerin görüşleri tabloda gösterilmiştir: 
Tablo 3. Öğretmenlerin Eğitim ve Dil Politikaları Üzerinde Siyasi, Sosyal, Ekonomik ve Toplumsal Değişimlerden Hangisinin Daha Çok Etkili Olduğuna İlişkin Görüşleri

\begin{tabular}{ll}
\hline Siyasi & Ö1-Ö3-Ö5-Ö6-Ö8-Ö9-Ö12-Ö14-Ö15 \\
\hline Sosyal & Ö7-Ö11 \\
\hline Ekonomik ve siyasi & Ö2-Ö4-Ö10-Ö13 \\
\hline
\end{tabular}

Öğretmenlere göre (9 öğretmen) eğitim ve dil politikalarını en çok siyasi değiş̧imler etkilemektedir.

"Ya zaten bizim ülkemizde her şey siyasetle doğru orantıll. Yani sadece bunu eğitim ve dil olarak değil bütün alana yayabilirsiniz. Mevcut iktidar kimin elindeyse ona göre diğer politikalarda olduğu gibi ĕ̆itim politikası da dil politikası da şekilleniyor (Ö1)".

"Siyasi değişiklikler ve üstlerimizdeki özellikle Bakanlıktaki yetkililer her gelen farklı bir sistemle geldiği için eğitim ve dil politikalarını etkiliyor. Öğrencilerin birinci sinıftan sekizinci sınıfa kadar iki üç sistem değistirdiği oldu (Ö3)".

"Siyasi olaylar bence değişime daha fazla öncelik kazandırtyor diye düşünüyorum. Siyaset daha fazla eğitimin içerisine girmiş ve bunun, eğitimdeki değişimin temel faktörü olduğunu düşünüyorum (Ö6)".

"Ben özellikle siyasi gelişmelerin dil politikaları üzerinde etkili olduğunu düşünüyorum (Ö8)".

4 öğretmene göre (Ö2, Ö4, Ö10, Ö13) ise eğitim ve dil politikalarını en çok ekonomik ve siyasi değişimler etkilemektedir:

"Ekonomik değişim tabii ki. Siyasal değişimler de çok etkilidir diye düşün̈̈yorum (Ö2)”.

"Iktidarda kim varsa ister istemez kendisine göre bir eğitimin politikası düzenliyor. Ekonomik değişimler de etkiliyor. Ekonomik anlamda mesela krizler oluyor gerçekten de halkın alım gücü azaldı̆̆ında bu ĕgitime yansiyor (Ö10)".

"Siyasi ve ekonomik eğilimler daha etkili (Ö13)".

2 öğretmen ise (Ö7, Ö11) sosyal değişimlerin etkili olduğunu belirtmiştir:

"Sosyal değişmelerin daha çok etkili olduğunu düşünüyorum (Ö11)".

\section{Öğretmenlerin Son 10 Yılda (2004-2014) Eğitim ve Dil Politikalarında Ciddi Bir Değişimin Olup Olmadığına İlişkin Görüşleri}

Öğretmenlere son 10 yılda (2004-2014) eğitim ve dil politikalarında ciddi bir değişimin olup olmadığ1 sorulmuştur. Öğretmenlere göre (13 öğretmen) son 10 yılda eğitim ve dil politikalarında ciddi bir değişim yaşanmıştır. Yaşanan bu değişimlerin ise genel olarak olumsuz olduğu belirtilmiştir. 4 öğretmen (Ö2, Ö4, Ö5, Ö6) ise yaşanan değişimlerin olumlu olduğunu belirtmiştir. Öğretmen görüşleri incelendiğinde eğitim ve dil politikası konusunda yaşanan olumsuz değişimlerin genellikle sınav sistemlerinin sürekli değişmesi üzerinde yoğunlaştığı ve Türk dilinin yozlaştırıldığı şeklinde olduğu görülmüştür. Olumlu değişimlerin ise daha çok öğretim yöntemlerinin geliştirilmesi ve eğitimde teknolojinin kullanılması üzerinde durulduğu anlaşılmıştır: 
"Yani tabii ki değişim görüyorum ama bu değişim olumlu yönde değil kanaatimce. Eğitim politikamız maalesef gün geçtikte içinden çıkılmaz bir kaosa sürükleniyor. En basitinden düşündüğümüz zaman, bir ülkede ortalama iki senede bir sınav sistemi değişir mi? Hani bırakın lise, üniversite öğrencisini, o yaştaki çocuk bile hocam ne olacă̆ız diyor. Çocuk bu kaygıyı yaşlyor. Çocuklar olsun, ögretmenler olsun, veliler olsun herkes bir kaygl içerisinde yani. Hani değişme var ama bu değişimler olumsuz yönde diyorum (Ö1)".

"10 yılda Türkçe ögretimi konusunda mesela öğretim yöntemi olarak hani ögretmen merkezliden öğrenci merkezliye, yapılandırmacı sisteme geçiş çok büyük bir geçişti. Bence bu program iyi mi evet daha iyi diyebilirim yani (Ö4)".

"Dil politikalarında ciddi bir değişim yaşandiğını şöyle düşünüyorum. Daha önce benim göreve başladığım yıllarda bu tip azınlıkların dillerini konuşması yönünde yapılan herhangi bir çalışma yoktu. Zaman içerisinde bu azınlıklara kendi dillerini konuşma, onlara ögrenme hakları tanındl. Bunlar bence önemli bir değişiklik. Ë̆itimde farklı yaklaşımlar bakanlık tarafindan yürürlüğe girdi çeşitli defalar ve bu yaklaşımlar uzun zamandır devam ediyor, sürdürülüyor (Ö6)".

"Tabii ki yaşandı. Illk başladığımız dönemdeki klasik sisteme ek olarak çoklu zekâ kuramlarl, ondan sonra 4+4+4'lerin getirdiği yenilikler, ciddi anlamda hepsini yaşadık (Ö9)".

"Eğitim politikası üzerinde çok ciddi değişimler yaşanıyor. Hatta on yıl içerisinde ü̧̧ dört tane çok ciddi değişimler yaşandl. Hatta bu değişimlere insanlar ayak uydurmakta da güçlük çekti. Gerek liselere geçiş sinavi olsun, gerek üniversiteye geçiş sinavi olsun zırt pırt her yıl değişiyor. Olmadl ertesi yll tekrar yenisini getiriyorlar. Dolaylsiyla bu kadar sık değişim öğrenciler üzerinde, veliler üzerinde olumsuz bir etki oluşturuyor. Buna olumlu bir etki diyemem. Dil açısından yaklaşmak gerekirse her geçen gün Türkçe dili daha da fazla yozlaşıyor (Ö12)".

2 öğretmen (Ö8, Ö10) ise ciddi bir değişimin yaşanmadı̆̆ını belirtmiştir:

"Eğitim konusunda hani çok büyük bir değişiklik olduğunu düşünmüyorum. Özellikle ben bu konuda TDK'nin pasif kaldığına inanıyorum. Dilin korunması, gelişmesi açısından biraz pasif kaldığını düşünüyorum (Ö8)”.

\section{Öğretmenlerin Üniversitede Aldıkları Eğitimin Şu Anki Türkçe Öğretim Programının Getirdiği Yenilikleri Uygulamalarına Katkısı Hakkındaki Görüşleri}

Öğretmenlere üniversitede aldıkları eğitimin şu anki Türkçe öğretim programının getirdiği yenilikleri uygulamalarına katkısı olup olmadığı sorulmuştur.

10 öğretmen üniversitede aldıkları eğitimin şu anki Türkçe öğretim programının getirdiği yenilikleri uygulamalarına katkısı olduğunu belirtmişken; 5 öğretmen (Ö1, Ö2, Ö10, Ö13, Ö14) ise aldıkları eğitimin katkısı olmadığını söylemiştir:

"Şimdi biz okula başladığımı yıllarda Türkçe Öğretmenliği daha yeni bir bölümdü, çoğunluğu edebiyat ă̆ırlıklıydı. Bence biz onun olumsuz yönde etkisini hissettik. Nasıl oldu, bizim derslerimizin çoğunluğu edebiyat ăgırlıklıydl. Mesela biz coğrafya dersi aldık 4 sene boyunca. Ben hâlâ anlamış değilim o kadar fazla coğrafyayı biz niye gördük diye. Bir 
coğrafya ögretmeninin alabileceği tüm dersleri aldık yani. Fayda etmedi, benim hiçbir işime yaramadl. Dil bilgisi yönünden de mezun olduktan sonra yine kendimi geliştirmek için kendi imkânlarımla bazı şeyler yaptım (Ö1)".

"Tabii ki oldu. Mesela sinıf yönetimi dersimiz vardl. Sinıf yönetimi dersinde çok şey ögrrendik, bize çok şey kattı. Materyal geliştirme ve özel ögretim dersi, bunların çok büyük katkısı var, hâlâ kullanıyoruz (Ö3)".

"Evet tabii ki üniversitede aldığımız teorik dersler bizim ögretmenlik yaptığımızda, ögretmenlik mesleğini icra ederken en büyük yardımcımız. Orada temel bilgileri alıyoruz. Sinıf yönetimi, ögrenci yaklaşımı, iletişim dersleri. Bunlar tabii ki ögretmenliğin temel vasıflarını kazanmak için çok önemli. Ama tabii bunun bir de mutfak aşaması dediğimiz ikinci safhası uygulamada yaşayarak ögrenilen tecrübeler çok önemli. Bu da üniversitenin vermis olduğu uygulama dersi ile bu kazanımlar elde ediliyor. Ama tabii ki en büyük kazanım kişinin göreve başladı̆̆ zaman sınıf ortamını birebir canlı kendi başına yaşama süreciyle beraber kazanılıyor bu deneyim. Öğretmenlik yüzde elli teoriyse, yüzde elli de pratikte meydana geliyor (Ö6)".

"Hiçbir katkısı olmadl. Gördüğ̈̈müz dil bilgisi tamamen ayriydı edebiyat mezunu olunca. Hani Türkoloji gibi tamamen Türk dilleriyle ilgili veya edebiyatçılarla ilgili. Lisede ögretmen olsaydım mutlaka olurdu, ama ilkögretimde hiç katkısı olmadı (Ö13)."

"Hiç etkili olmadl. Ben kendi lise bilgilerimle, üniversiteye hazırlandlğım dil bilgisi konularıyla başladım (Ö14)".

\section{Öğretmenlerin 10 Yıl Önceki ile Şu Anki Türkçe Öğretimi Ders Materyalleri ve Öğrenme Ortamı Açısından Yaşanan Farklılıklar Konusundaki Görüşleri}

Öğretmenlere 10 yıl önceki ile şu anki Türkçe öğretimi ders materyalleri ve öğrenme ortamı açısından değişim olup olmadığı sorulmuştur. 14 öğretmen bu konuda ciddi değişimler yaşand1ğını ifade ederken, sadece 1 öğretmen (Ö10) değişim yaşanmadığını söylemiştir. Öğretmenlere göre yaşanan en önemli değişimler; iletişim ve teknolojinin eğitimde yer alması, ders materyallerinin zenginleşmesi ve ders kitaplarının yenilenmesi ve iyileştirilmesidir:

"Tebeşir, onu bile bulamıyorduk bazen. Bir kitabımız vardı ama şu an internetimiz var, her sinıfta bilgisayarımız var. Artık tebeşir kullanmıyoruz, projeksiyon makinelerimizi kullaniyoruz, farklı materyaller kullantyoruz. Ders materyalleri açısından tabii bunun eğitim sisteminin gelişmesiyle değil de teknolojinin gelişmesiyle, teknolojinin eğitim sistemine girmesiyle, monte edilmesiyle sağland (Ö3)".

"Öğrencilerin bilgiye erişimi kolaylaştı. Böyle eskiden çocuklar ansiklopediden araştırırlardl işte. Şimdi tıklıyorlar, google'den giriyorlar, bir çıtı alıp geliyorlar (Ö7)".

"Hayır hayır, mesela ögrenci profiline baktı̆̆ımızda da bir değissiklik yok. Hatta dediğim gibi iletişim araçlarının da gelişmesi bunu olumsuz anlamda etkiliyor. Mesela benim daha önce, sekiz dokuz yıl önce mezun olan ögrencilerim var, onlar çok daha ilgililerdi. Fakat şimdiki ögrenci profiline baktığımda çok daha ilgisizler maalesef. Öğretim materyalleri açısından da olmadı. Ben başladığım yılla şimdi bakıyorum materyal açısından açıkçası ben bir değişiklik göremiyorum. Yani bu konuda bir 
değişiklik, bir artı bir şey olmadı. Bizim projeksiyon falan yok çoğu sınıfimızda (Ö10)".

"Bilim ve teknolojik alanda evet. Önceden tepegöz kullaniyorduk biz üniversitedeyken ya da ilk başladiğımız yıllarda. Saydamlar vardı. Ama şimdi projeksiyon kullanıyoruz. Yakında akıllı tahtalara geçeceğiz (Ö11)”.

\section{Öğretmenlerin, Derslerinde Teknolojiden Yararlanma Durumları ve Bu Yararlanmanın Öğrenciler Üzerindeki Olumlu ve Olumsuz Etkilerine İlişkin Görüşleri}

Öğretmenlere işledikleri derslerde teknolojiden yararlanma durumları sorulmuştur. 14 öğretmen işledikleri derslerde teknolojiden yararlandıklarını söylemiştir. 1 öğretmen (Ö10) ise okulun fiziki şartlarından dolayı istese de teknolojiden yararlanamadığını söylemiştir. Öğretmenlere göre işlenen derste teknolojiden yararlanmalarının öğrenciler üzerindeki olumlu etkileri şu şekilde belirtilmiştir:

- Öğrencilerin ilgisini çekiyor.

- Dersi zevkle dinliyorlar.

- Bütün duyularına hitap ettiği için öğrenmeleri kalıcı oluyor.

- Dersi anlamaları kolaylaşıyor.

- Bilgiye kısa sürede ulaşıyorlar.

- Derse güdülenmeleri kolaylaşıyor.

- Başarıları artıyor.

Öğretmenler, derste teknolojinin çok fazla kullanıldığında ise öğrencileri sıktığını ve dersi monotonlaştırdığını belirtmişlerdir.

"Teknolojiyi fazla kullanmak da eğitimi olumsuz etkileyebilir. Yani bunu dozunda bırakmak, çocuğun ilgisini çekmesi bakımından çok önemli. Tabii ki yani dersi zevkli hâle getiriyor tabi (Ö2)".

"Yararlanamıyoruz tam anlamıyla. Yani çünkü fiziki şartlar, okulun şartları etkiliyor. Öğrencilere kesinlikle katkı sağlar. Çünkü hep diyorum, ne kadar çok duyuya hitap ederse bilgi o kadar faydalı olacaktır ve onunla beraber birçok duyuya hitap edeceği için ben faydalı olacağını düşünüyorum (Ö10)".

"Hem daha zevkli hâle getiriyor hem de görsel-işitsel olarak etkileniyorlar. Ekonomik olarak zaylf bir yer okulumuz. Bu yüzden her ögrenci ilave test alamıyor ya da yetmiyor kitabımız. Konuları pekiştirmek için tahtaya yansittı̆ı̆mı testleri kullaniyoruz. Olumsuz yönüne gelirsek ben olumsuz bir yönüyle karşılaşmadım (Ö11)".

"Teknoloji mutlaka olması gerekiyor. Yani ögrenci daha hızlı bilgiye erişiyor, bizim için de kolaylık oluyor (Ö13)".

Öğretmenlerin Önceki Türkçe Öğretim Programı (1981) ile Şu Anda Uygulamada Olan Türkçe Öğretim Programı Arasındaki Belirgin Farklııklara İlişkin Görüşleri

Öğretmenlere önceki Türkçe öğretim programı (1981) ile şu anda uygulamada olan Türkçe öğretim programı arasındaki belirgin farklılık olup olmadığı sorulmuştur. Öğretmenler iki program arasında birçok farklılık olduğunu belirtmişlerdir. 13 öğretmen uygulamada olan programın eski programa göre daha başarılı olduğunu söylemiştir. 1 öğretmen (Ö8) eski programın daha başarılı olduğunu, 1 öğretmen (Ö7) ise iki program arasında farklılık olmadığını ifade 
etmiştir. Öğretmenler uygulamada olan programın olumlu yönlerini şu şekilde belirtmiştir:

- En önemli fark öğrencinin merkeze alınması. Öğrenci merkezli eğitim öğrenciyi aktif kiliyor.

- Dil becerilerinin öğretimi açısından eski programa göre daha etkili

- Ölçme-değerlendirme açısından zenginlik var. Değerlendirmeler daha objektif yapılabiliyor.

- Öğretmenin yükü azaldı, rehber konumda.

- Hem öğretmeni hem de öğrenciyi yönlendirici, yol gösterici.

- Öğrenci derse hazır geliyor.

- Daha iyi, daha anlaşıllır.

Öğretmenler uygulamada olan programın olumsuz yönlerini ise şu şekilde belirtmiştir:

- Öğretmen soyutlaştırıldı, pasifize edildi.

- Program ve konular yetişmiyor.

- Dil bilgisi öğretimi açısından sıkıntı var.

- Performans ve proje ödevleri gereksiz olmaya başladı.

- Okuma ve yazma hızı düştü el yazısı dayatmasından.

- Programı uygulamak için ortam ve fiziki şartlar çok eksik. Sınıf mevcudunun fazla olması programı uygulamada sıkıntı yaratıyor.

"En önemli fark çocuğun merkeze alınması. Önceden öğretmen anlatırdl, konuşurdu, yazar, çizerdi, yazdırırdl, geçer giderdi. Ama şimdi öğretmen yüzdelik olarak alırsak dersin yüzde otuzunda kırkında aktif. Biraz daha yönlendiren konumunda artık(Ö2)".

"İkisi arasında çok belirgin farklılık var. İşte yapılandırıcı yaklaşım. En büyük fark bu bence. Olumsuz diyebileceğim hani yönlerinden bir tanesi ögrenciye işte performans ödevleri mesela işte proje yani çocuk zorunlu. Zorunlu aldiğl zaman sanki performans görevlerini mesela biraz da aileye yük biniyor bu performans görevlerinde. Yani zaten ailenin yaptığını düşünüyorum. Ödevler geliyor mesela, belli hani aile yardım etmiş (Ö4)". "Uygulama açısından fark yok (Ö7)".

"Ya ben daha çok eski programın faydalı olduğunu düşünüyorum bu konuda. Özellikle dil bilgisi konusunda. Şimdi şöyle sılkntımız oluyor, yeni programda ögrenci merkezli eğitim olduğu için amaç, dil bilgisi konularına direkt giremiyoruz. Nedir ana başlık, ögrenciye sezdirmek. Maalesef ögrencilerimizin seviyesi buna uygun olmadĭ̆ için sılkıntılar çekebiliyoruz. Ve zaman zaman eski programa dönüş yapabiliyoruz bu konuda (Ö8)".

"Uygulamada olan program başarıll. Öğrencilerle olan ilişkim de daha bir yakınlaştı. Çünkü onlar yazıya döküyorlar ve onların kişiliklerini daha iyi anlayabiliyorum. Ruh halleri nasıldır, yazdıkları kompozisyonlarda, günlüklerde, ödevlerde yaşadıklar problemler bile çıkıyor. Ona göre çocuğa yaklaşımım da değişiyor (Ö14)".

\section{Programda Yer Alan Dil Becerilerine İlișkin Öğretmen Görüşleri}

Öğretmenlere göre (10 öğretmen) uygulamada olan programda en çok okuma becerisine önem verilmiştir. Bazı öğretmenler (7 öğretmen) dil bilgisi becerisinin öğretiminde sıkıntılar yaşand1ğını söylemişlerdir: 
"Ben 5. sinıflara derse girdiğimde dinleniyorum, demiști bir hocam bana. Çünkü dil bilgisi namına hiçbir şey yoktu 5. sinıfta, hâlâ yok zaten. 5. sınıf bir geçiş dönemi. Bizim sıkıntımız şu oldu. 5. sinıfta önceden sınıf ögretmenleri olmamasına rağmen 4 ve 5. sinıfta dil bilgisi konuların veriyorlardı ögrencilere. Öğrenci bize boş gelmiyordu ama şu an 5. sinıfta hiçbir konu olmadiğı için öğrenciler boş geliyor ve 6. sinıfta velilerin en büyük şikâyeti şu: 5. sinıfta bu çocuğun notları diyor dörttü, beşti Türkçe notları. 6. sınıfa geldi, çok düştü (Ö3)”.

"Dil bilgisi mesela 5. siniflarda önemi daha az, 6. siniflarda en başta neredeyse. 7 ve 8. siniflarda ortalarda yani. Mesela biz hep diyoruz zümre toplantılarında, 6. sinıfin dil bilgisi daha yoğun, yani 5. sinıflarda çok bir şey yok, hiçbir şey yok. Yani mesela 8. sinıflarda az. 8. sinıf çocuğundan biz tabii şey bekliyoruz işte, geçmişteki ögrendiklerini hatırlamalarını bekliyoruz. 8. sinıflarda mesela çok az konu var. 5. sınıfta daha az dil bilgisi var. 6. sinıfin ilk konuları bence 5. sınıfa çekilebilir diye düşünüyorum ben. Çünkü 6. sinıf biraz daha yoğun yani. Çünkü sözcük türlerine de giriyorsunuz. Sözcük türlerini de işliyorsunuz fiil hariç. Yani o 6. stnufları biraz zorluyor (Ö4)".

"Dil bilgisi konularının ağırlıklı olduğu dönemler var, 6. sinıflar mesela. Özellikle 5. sınıf çok hafif, 6. sınıf çok ağır. 7. sınıf biraz hafif diye düşünebilirsiniz ama 7. sinıf çocukların yaş olarak bir geçiş dönemi olduğu dönem, çok zorlaniyorlar. 8. sınıf zaten sınav dönemi, liselere girmek için ayrı bir hazırlı̆̆ın yapıldi ̆̆ı dönem (Ö5)".

\section{Öğretmenlerin Önceki Programa (1981) Göre Hazırlanan Ders Kitapları ile Şu Anki Programa Uygun Hazırlanan Ders Kitapları Arasındaki Farklılıklara İlişkin Görüşleri}

Öğretmenlere önceki programa göre hazırlanan ders kitapları ile şu anki programa göre hazırlanan ders kitapları arasında farklılık olup olmadığı sorulmuştur. 2 öğretmen (Ö7, Ö8) dışında diğer öğretmenler uygulamada olan programa uygun hazırlanmış ders kitaplarının eski programa göre hazırlanmış ders kitaplarından daha iyi olduğu görüşünü belirtmişlerdir. Öğretmenler görselliğin ön planda olması, kitapta konuyla ilgili bolca etkinliklerin yer alması, öğretmen ve öğrenciyi yönlendirmesi, metinlerin ilgi çekici olması, ölçme-değerlendirme açısından çok iyi olması bakımlarından uygulamada olan programa uygun hazırlanan kitapların daha iyi olduğunu ifade etmişlerdir:

"Fark eden bir şey yok diyeceğim ama hazırlama aşamasında bu işin mutfağında olanlara çok sorulmadan, danışllmadan böyle bir şey hazırlandiğı için başarıya ulaşmakta çok zorlaniyoruz. Ben 7. sinıfların kitaplarını beğenmem. Mesela 5. sinıfları ortaokula aldılar, şöyle bir kitabına bakarsanız 5.sınıf Türkçe kitabında hiçbir şey yok. Hiçbir şey yok, 40 tane parça var, 40 tane parçada anlamını bilmediğimiz kelimeleri öğrenecek çocuk. Bunun konusu nedir, ana fikri nedir, türü nedir onu ögrenecek. Başka hiçbir şey ögrrenmeyecek. 7. sinıfların kitabını derseniz tamamen üniversite ögretim elemanları tarafindan, üniversite ögrencilerine hitap eden parçalar seçilmiş ve Türk dilini ögrretmek, sevdirmek, inceliklerini kavratmak adına verilebilecek hiçbir şey yok. Ve bunu müfettiş̧lere sikça dile getirip söylüyoruz ama hani onların da herhâlde yapabildikleri bir şeyler yok (Ö7)".

"Metnin işlenişi açısından eski kitaplar daha yönlendiriciydi. Şimdiki 
kitaplarda öyle hem ögretmen hem ögrrenci daha fazla böyle bir araştırmaya yönelik olduğu için daha fazla zaman harcamak zorundayız (Ö8)". "Yeni kitapları daha çok beğeniyorum. Sinava yönelik özellikle uzun paragrafların olması iyi, şu anki kitaplardan gayet memnunum. Öğrenciler de zevk alıyor (Ö14)".

\section{Uygulamada Olan Programa Göre Hazırlanmış Ders Kitaplarının Olumsuz Yönleri Hak- kında Öğretmen Görüşleri}

Öğretmenler (11 öğretmen), uygulamada olan programa göre hazırlanmış ders kitaplarının en olumsuz yönünün metinlerin uzunluğu olduğu konusunda görüş bildirmişlerdir:

"Okuma metinleri çok uzun. Mesela geçen 7. sınıfta, aklımda değil şimdi ama neredeyse bir yirmi dakika okuduk yani onu söyleyeyim (Ö2)".

"Maalesef ilimizde de Türkiye genelinde de Türkçe zümresi olarak biz bu konudan şikâyetçiyiz. Çok fazla uzun metinler var. Algılama düzeyi çocukların biraz düşük olduğu için anlamakta, yorumlamakta, yorumladığını dile getirmekte hani biraz zorlaniyorlar. Bu konuyla ilgili hem Millî Ĕ̆itim Müdürlügüne hem Bakanlığına birçok defa raporlar iletildi; fakat nedense bir türlü gündeme alınmadl. Metinler çok uzun. 6. sinıflarda bile çok uzun. Algllamada bazı problemlerimiz var. Hatta ben küçük bir örnek vereyim size. 8. sinıflarda yanılmıyorsam Çalıkuşu romanını biliyorsunuz. Oradan bir kesit yaklaşık 7-8 sayfalık bir kesit. Şöyle bir sorunumuz oldu. Metinden hareketle ne yapmamı lazım, metnin türünü ögrencilere kavratmamı lazım. Hani ben kavrayamıyorum ki çocuk nasıl kavrasın? (Ö8)".

"Özellikle bu seneki kitaplarda özellikle 7. sinıflarda bir kitabımız var, yani gerçekten öyle metinler var ki üniversite ögrencilerinin bile algılamakta zorluk çekebileceği metinler var maalesef (Ö10)".

"Bu yıl 8. sinıflar için kullandiğımız metinler çok uzun ve sıkıcı metinler. 7. sınıf için senelerdir kullandığım bir yayınevi kitabının başlangıcındaki metin o kadar sıkıcı ki çocuklar biz 7. sinıfa nereden geldik diyor. 7. sinıf Türkçe dersinden gözleri korkuyor bir kere o metinlerle. 6. sinıfta da işte değişmeler, yeniliklerle ilgili metinler çok uçuk kaçık. Çocukların alay edebileceği metinler (Ö11)".

Uygulamada olan programa göre hazırlanan kitaplar hakkında 3 ögretmen (Ö5, Ö12, Ö15) özellikle dil bilgisi ögretimi konusunda etkinliklerin yeterli olmadı̆̆ını söylemiştir:

"Dil bilgisi etkinlikleri biraz daha az. Yani 8 etkinlik varsa bir parçayla ilgili, bunlardan 7 tanesi okuma anlama, yazma, 1 tanesi ise dil bilgisi ile ilgili (Ö5)".

"Dil bilgisi etkinlikleri olarak maalesef günümüz çalışma kitaplarındaki etkinlikler yeterli değil. Çok az veriliyor. Çocuğun bir isim tamlamasını sekiz, on örnekle ögrrenmesine, kavramasina imkân yok. Dolayısıla daha geniş tutulmasl, daha somut olması gerekirdi. Ben kendim kişisel olarak özel yayınevlerinin hazırlamış olduğu CD'lerden yararlanıyorum çocuklara ögretebilmek için (Ö12)".

"Dil bilgisi ile ilgili etkinliklerin sayısı gerçekten çok az ve çok kısa tutulmuş, çok basitleştirilmiş ama yapılan ortak sınavlarda bu kadar basit hâliyle çıkmıyor karşılarına ögrencilerin. Daha çok zorlanıyorlar (Ö15)”". 
Öğretmenlerin tümü okutmak istediği kitabı kendilerinin seçmesi gerektiğini ifade etmiştir. Öğretmenler, kitap seçimi konusunda genelde kendilerine sorulduğunu ancak bunun dikkate alınmadığını belirtmişlerdir:

"Bize her sene kitaplarla ilgili, içeriğiyle ilgili hemen hemen her sene sorular soruluyor, anket yapıllyor, beğenip beğenmediğimiz soruluyor. Ama yıllardır yayınevleri kitapları değisstirmiyor. Artık metinleri gözüm havada okuyabiliyorum (Ö9)".

\section{Kitap Tercihi Hakkında Öğretmen Görüşleri}

Öğretmenlere "MEB'in kitaplarını mı yoksa özel yayınevlerinin kitaplarını mı tercih edesiniz?" diye sorulduğunda, 13 öğretmen MEB'in kitaplarını tercih ettiklerini belirtmişlerdir. 1 öğretmen (Ö12) özel yayınevlerinin hazırladığı kitapları tercih ettiğini belirtirken, 1 öğretmen (Ö11) ise MEB ya da özel yayınevleri gibi bir ayrım yapmadığını ifade etmiştir:
“MEB'in kitaplarının daha iyi olduğunu düşünüyorum ben. Daha anlaşı- lır, daha net. Mesela bu sene kullandiğım özel bir yayınevinin kitabı da- ha karmaşık zor geliyor bana. Konuya hazırlanırken, konuyu işlerken baktığımda çok daha uzun konu ele alınmış ama bu karmaşıklı̆̆ı da meydana getirmiş. Anlaşılması biraz daha zor geliyor bana (Ö6)".
"Tercih değil de ben çok iyi incelenmesinden yanayım. Özel ya da Millî Eğitim diye bir ayrım yapmiyorum (Ö11)".
"Millî Ĕgitim Bakanlığıyla özel yayınevlerini kıyasladığım zaman, bazı özel yayınevlerinin hazırlamış olduğu kitaplar gerçekten çok iyi (Ö12)”.

Öğretmenlerin hem Günlük Hayatta hem de Öğrencileriyle İlişkilerinde Türkçenin Kullanımıyla İlgili Yaşadığı Sorunlar ve Bu Sorunların Çözüme Kavuşturulabilmesi Hakkındaki Görüşleri:

Öğretmenlere hem günlük hayatta hem de öğrencileri ile ilişkilerinde Türkçenin kullanımıyla ilgili ne gibi sorunlar yaşandığı ve bu sorunları çözüme kavuşturabilmek için neler yapılabileceği sorulmuştur. Öğretmenlerin ifadelerine göre Türkçenin kullanımıyla ilgili yaşanan olumsuzluklar şu şekilde özetlenebilir:

- Sorunların en büyük kaynağı internet, sosyal paylaşım siteleri. İnternet, dilin kullanılmasını çok etkiliyor.

- Kitle iletişim araçları öğrencinin Türkçeyi doğru kullanmasını etkiliyor.

- Argo sözcüklerin kullanımı.

- Yerel söyleyişlerin kullanımı.

- Az sözle çok şey anlatma isteği, sözcük dağarcığının fakirleşmesi.

Öğretmenler bu sorunların çözüme kavuşturulmasında en önemli görevin ebeveynler ve öğretmenlere düştüğünü belirtmişlerdir. TDK, RTÜK, TBMM ve belediyelere de dilin özenli kullanılması konusunda önemli görevler düştüğü vurgulanmıştır:

"Türkçe kullanımına yönelik sorunlar illaki var. Mesela yerel ağızla konuşma tabii ki bulunduğumuz ilde var, bunu engellemek de biraz zor diye düşünüyorum. Bir de internet dili. Çocuklar sosyal paylaşım sitelerinde sizler sohbet ederken kullandiğınız kelimeler veya bu kelimeleri yazış biçiminiz Türkçe kurallarına veya bizim bildiğimiz şeylere aykırı, deriz her zaman. Fakat şöyle bir dil oluşmuş, yani artık internet dili oluşmuş. Bu dil de o paylaşım sitelerini kullanan kişiye çok kolay geli- 
yor. Uzun uzun yazmaktansa kısa kisa yazıp bu şekilde anlaşıyorlar. Ama argo sözcükleri kullanma açısından çocuklarımızın üzerine düşülmesi gerekiyor bu eğitim sistemi açısından. Velilerin çok dikkatli olması lazım bilhassa (Ö2)".

"Yozlaşmanın olduğunu düşünüyorum. Çocuklar çok konuşma taraftarı değil, az sözle çok şey ifade etmeye, böyle davrandıklarında popüler olduklarını, ilgi çektiklerini, kaba, seviyesiz olduklarını da böyle işte popüler olduklarını düsünüyorlar. Sosyal medyanın ya da kitle iletişim araçlarının da etkisi olduğunu düşünüyorum (Ö7)”.

"Öğrenciler dili çok özensiz kullanıyorlar. Medya, internet bunda etkili. Kitle iletişim araçları, sosyal ağlar, facebook gibi twitter gibi kesinlikle çok olumsuz etkiliyor öğrencileri. Benimle konuşurken yazarken dikkat ediyorlar ama kendi aralarında konuşurken biliyorum ki çok büyük yanlışlıklar içindeler. Bu konuda TDK belki bir adım atmall, bu konuda bir şeyler yapllmall. Hatta siyasiler devreye girmeli. Belediyeler bence çok öncü olabilirler. Mesela Giresun Belediyesi böyle bir kampanya başlatabilir, en basitinden çevredeki işyerlerinden başlatabilir (Ö10)". "Genel olarak dili özenli kullanmiyorlar bence. Kendi Türkçe dersimde bile çocuklara bir soru sorduğumda çocuklar kısa olarak evet ya da hayır demeden ziyade Ingilizce yes ya da no diye karşıllk veriyorlar. Ö̆gretmenim demeden teacher diyorlar. Siz de zannediyorsunuz ki Ingilizceyi çok iyi biliyor. Hayır, İngilizceleri de çok zaylf genel olarak bütün okulun. Bu sadece bir özentiden kaynaklaniyor. Kitle iletişim araçları son derece olumsuz yönde etkiliyor dilimizi maalesef. Dilimiz özellikle iletişim araçları sayesinde git gide yozlaşıyor ve yine çözüm TBMM'den geçiyor (Ö12)".

\section{Sonuç, Tartışma ve Öneriler}

Türkiye'de son 10 yılda (2004-2014) eğitim ve dil politikalarında yaşanan değişimlerin Türkçe eğitimine yansıması hakkında Giresun ilinde görev yapan ortaokul Türkçe öğretmenlerinin görüşlerinden faydalanılmıştır. Öğretmenlerle yapılan görüşmeler neticesinde elde edilen sonuçları şu şekilde özetlemek mümkündür:

- Öğretmenlere göre, ülkemizdeki eğitim ve dil politikalarının belirlenmesinde daha çok çağdaş yaklaşımlar ön plana alınmaktadır. Ülkemizdeki eğitim ve dil politikalarının belirlenmesinde hem çağdaş yaklaşımlar hem de millî değerler sentezlenerek ele alınmalıdır.

- Öğretmenlere göre ülkemizde eğitim ve dil politikalarını en çok belirleyici olan ulusal kurumlar Millî Eğitim Bakanlığı ve Türk Dil Kurumudur. Uluslararası kurum ve kuruluşlar olarak ise eğitim ve dil politikalarını en çok etkileyen kurumun Avrupa Birliği olduğu ifade edilmiştir.

- Öğretmenlerin tümü eğitim ve dil politikaları üzerinde siyasi, sosyal, ekonomik ve toplumsal değişimlerin eğitim ve dil politikaları üzerinde etkisi olduğunu ifade etmişlerdir. Öğretmenlere göre eğitim ve dil politikalarını en çok siyasi değişimler etkilemektedir. Bu sonuç, Yılmaz \& Altınkurt (2011) tarafından öğretmen adaylarıyla yapılan çalışma bulgularıyla benzerlik göstermektedir. Araştırmaya katılan öğretmen adaylarına göre eğitim sistemindeki önemli sorunlardan biri de gücü elinde bulunduran iktidar partilerinin sisteme sikl1kla ve ideolojik nedenlerle müdahalede bulunması gelmektedir. Benzer bir sonuca Kartal (2013) tarafindan öğretmen adaylarıyla yapılan çalışmada da rastlanmıştır. Öğretmen adayları eğitimin siyasetten arındırılmasını ve sistemin yeniden düzenlenmesi görüşünü ifade etmişlerdir. 
Kösterelioğlu ve Bayar (2014) tarafindan 23 öğretmenle yapılan ve Türk eğitim sisteminde en çok karşılaşılan problemlerin araştırıldığ 1 çalışmada, eğitim politikalarının siyasetin etkisinde kaldığı görüşü öğretmenler tarafından belirtilmiştir. Bu bulgu da ulaşılan sonucu destekler niteliktedir. Ayrıca Duman vd. (2014) tarafindan yapılan çalışmada da, öğretmen adayları yapılan eğitim reformlarının siyasi kaygılarla gerçekleştirildiğini belirtmişlerdir.

- Öğretmenler eğitim ve dil politikaları üzerinde siyasi, sosyal, ekonomik ve toplumsal değişimlerin eğitim ve dil politikalarını etkilememesi gerektiğini söylemişlerdir.

- Öğretmenlere göre son 10 yılda eğitim ve dil politikalarında ciddi bir değişim yaşanmıştır. Yaşanan bu değişimlerin ise genel olarak olumsuz olduğu belirtilmiştir. Öğretmen görüşleri incelendiğinde eğitim ve dil politikası konusunda yaşanan olumsuz değişimlerin genellikle sınav sistemlerinin sürekli değişmesi üzerinde yoğunlaştığı ve Türk dilinin yozlaştırıldığ şeklinde olduğu görülmüştür. Olumlu değişimlerin ise daha çok öğretim yöntemlerinin geliştirilmesi ve eğitimde teknolojinin kullanılması üzerinde durulduğu anlaşılmıştır.

- Öğretmenler üniversitede aldıkları eğitimin, şu anki Türkçe öğretim programının getirdiği yenilikleri uygulamalarına katkısı olduğunu belirtmişlerdir.

- Öğretmenler şu anda uygulamakta oldukları programla ilgili hizmet içi eğitim aldıklarını belirtmişler, ancak aldıkları eğitimin yararlı olmadığını ifade etmişlerdir. Bu sonuç, Kırmızı ve Akkaya (2009) tarafından yapılan Türkçe öğretimi programında yaşanan sorunlara ilişkin öğretmen görüşleri konulu çalışmayla benzerlik göstermektedir. Araştırmada, hizmet içi eğitim sürecine ilişkin ortaya konulan görüşler dikkate alındığında seminerlerin yeterince verimli geçmediği dile getirilmiştir. Benzer sonuçlara Karacaoğlu ve Acar (2010) tarafindan 82 öğretmenle yapılan araştırmada rastlamak mümkündür. Çalışmada öğretmenler, hizmet içi programların etkili olmadığını savunmuşlardır.

- Öğretmenlere göre 10 yıl önceki ile şu anki Türkçe öğretimi ders materyalleri ve öğrenme ortamı açısından ciddi değişimler yaşanmıştır. Öğretmenlere göre yaşanan en önemli değişimler; iletişim ve teknolojinin eğitimde yer alması, ders materyallerinin zenginleşmesi ve ders kitaplarının yenilenmesi ve iyileştirilmesidir.

- Öğretmenler, işledikleri derslerde teknolojiden yararlandıklarını söylemişlerdir. İşlenen derste teknolojiden yararlanmalarının öğrenciler üzerinde olumlu etkileri olduğunu belirtmişlerdir. Fidan (2008), Gülcü vd. (2013), Katrancı \& Uygun (2013) tarafından yapılan çalışmalarda da benzer sonuçlara ulaşıldığı görülmüştür. Ayrıca Dargut \& Çelik (2014) tarafindan yapılan çalışmada da Türkçe öğretmen adaylarının öğretimde teknoloji kullanımına ilişkin tutumlarının genel olarak olumlu olduğu sonucuna ulaşılmıştır.

- Öğretmenler iki program arasında birçok farkl1lık olduğunu belirtmişlerdir. Uygulamada olan programın eski programa göre daha başarılı olduğunu söylemişlerdir. Öğretmenlere göre uygulamada olan programda en çok okuma becerisine önem verilmiştir.

- Öğretmenler uygulamada olan programa uygun hazırlanmış ders kitaplarının eski programa göre hazırlanmış ders kitaplarından daha iyi olduğu görüşünü belirtmişlerdir. K1lı̧oğlu (2009) tarafindan yapılan çalışmada da benzer bulgulara rastlanmıştır. Çalışmada, öğretmenlere göre üç temel kitabın (öğretmen kılavuz kitabı, çalışma kitabı, ders kitabı) bazı eksiklikleri olmasına karşın etkili eğitim-öğretim yapılmasına fırsat verdiği ve etkinliklere dayalı ders işleme modelinin eğitimde kaliteyi arttırdı̆̆ı ifade edilmiştir. Öğretmenler, yeni programa göre hazırlanmış ders kitaplarının en olumsuz yönünün metinlerin uzunluğu olduğu konusunda görüş bildirmişlerdir. Bu sonuç, Kırmızı ve Akkaya (2009) tarafından yapılan Türkçe öğretimi programında yaşanan sorunlara ilişkin öğretmen görüşleri konulu çalışmayla benzerlik göstermektedir. Yapılan bu çalışmada da öğretmenler okuma metinlerinin çok uzun olduğunu belirtmişlerdir. Güven (2011) tarafından yapılan çalışmada da, öğretmen- 
ler ders kitaplarında yer alan metinlerin uzun, yetersiz ve ağır seviyede olduğunu belirtmişlerdir.

- Öğretmenlerin tümü okutmak istediği kitabı kendilerinin seçmesi gerektiğini ifade etmişlerdir. Öğretmenler, kitap seçimi konusunda genelde kendilerine sorulduğunu ancak bunun dikkate alınmadığını belirtmişlerdir. Öğretmenlere MEB'in kitaplarını mı yoksa özel yayınevlerinin kitaplarını mı tercih edersiniz, diye sorulduğunda MEB'in kitaplarını tercih ettiklerini belirtmişlerdir.

- Öğretmenler Türkçenin doğru kullanılmadığı ve dilin yozlaştırıldığg görüşünü belirtmişlerdir. Dilin kullanımını olumsuz anlamda en çok etkileyenler; internet, sosyal paylaşım siteleri, kitle iletişim araçlarıdır. Öğretmenler bu sorunların çözüme kavuşturulmasında en önemli görevin ebeveynler ve öğretmenlere düştüğünü belirtmişlerdir. Bu sonuç, Göçer (2014) tarafindan yapılan bir araştırmanın sonuçlarıyla benzerlik göstermektedir. Yapılan çalışmada, Türkçe öğretmeni adayları, Türkçenin karşı karşıya kaldığı sorunların oluşumunda, toplumda dil bilincinin oluşmamış olmasının, Türkçenin eğitimini verecek öğretmenlerin nitelikli yetiştirilmemesinin, kitle iletişim araçlarında Türkçenin kullanımında özenli davranılmamasının ve çocukların dili doğru edinmelerinde ailelerin sorumlu davranmamasının etkili olduğu görüşündedirler.

Elde edilen bu bulgu ve bilgilerin ışığında öğretmenlerin görüşlerinden de yararlanarak şu öneriler yapılabilir:

- Eğitim ve dil politikaları belirlenirken hem millî hem de çağdaş yaklaşımlar sentezlenerek ele alınmalıdır.

- Eğitim ve dil politikalarının belirlenmesinde uluslararası kurum ve kuruluşlardan ziyade ulusal kurum ve kuruluşlar etkili olmalıdır. Özellikle Millî Eğitim Bakanlığı ile Türk Dil Kurumunun etkinliği daha da artırılmalıdır. Eğitime ayrılan bütçe artırılarak dış kaynaklara olan bağl1lık en alt seviyeye getirilmelidir. Bu sayede küresel aktörlerin eğitim ve dil politikaları üzerine etkisi azaltılabilir.

- Eğitim ve dil politikalarını en çok siyasi değişimler etkilemektedir. Genellikle iktidara gelen yeni siyasi irade, bir önceki hükümetin eğitim politikasını değiştirmeye ve kendi politikasını uygulamaya çalışmıştır. Bu nedenle eğitimdeki asıl köklü değişiklik, bir önceki eğitim uygulamalarının değiştirilmesi olmuştur. Her yeni dönem, bir önceki dönemin uygulamalarını kaldırmaya çalışırken zaman kaybı yaşanmış, eğitim ve dilde ortak bir politika hayata geçirilememiştir. Eğitime ve dile politik müdahalelerin büyük etkisi olmuştur. Yaşanan bu sorunların giderilebilmesi için, XV. Millî Eğitim Şûrası'nda belirtildiği gibi, eğitim ve dil, mutlaka politikadan arındırılmalıdır (MEB, 1998). Devletin eğitim ve dil politikası uzun vadeli olmalıdır. Hükümetten hükümete veya kişiden kişiye değişen politikalardan vazgeçilmelidir.

- Hedeflenen politikalara ulaşılabilmesi için sağlam bir denetleme sistemine ihtiyaç duyulduğu düşünülmektedir. Bunun için şûra kararlarının buyurucu bir niteliği olması ya da bağımsız bir kuruldan oluşan bir kurumun kurulması önerilebilir. Bu kurum, siyasi irade tarafindan belirlenen politikaların uygulanabilirliğini saptayabilir ve uygulama noktasında değerlendirme ve denetleme görevini üstlenebilir. Böylece politikaların kâğıt üzerinde kalması engellenebilir.

- Son 10 yılda eğitim ve dil politikalarında olumlu olduğu kadar olumsuz anlamda da ciddi bir değişimin yaşandığı görülmektedir. Özellikle sınav sisteminin sürekli değişmesi bu olumsuzlukların en önemlisi olarak göze çarpmaktadır. Çoktan seçmeli testlerden çok anlama ve anlatma becerilerine yönelik ölçme ve değerlendirme araçlarının daha da geliştirilmesi önem arz etmektedir. 
- Öğretmenler derste okutmak istedikleri kitapları kendileri seçmek istemektedir. Kitap seçimi konusunda öğretmenlerin görüşlerinin dikkate alınması gerektiği düşünülmektedir.

- Türk dilinde yaşanan sorunların ana nedeni, dilin bütün yönleriyle ele alınarak çözümünü sağlayacak bir dil planlamasının yapılamamasıdır. Yapılması gereken en önemli şey, Türk dilinin korunması ve gelişmesi için devletin izleyeceği millî bir dil politikasının meydana getirilmesi ve dilin korunması ile ilgili yasaların bir an önce çıkarılmasıdır. Özellikle AB adaylığ1 sürecinde dille ilgili millî bir politika izlenmesi gerekmektedir. İzlenecek olan bu politika resmiyete dökülmeli ve kararlılıkla uygulanmalıdır. Dil planlaması çalışmalarına bilimsel bir temelde ağırlık verilmelidir. Türkiye'nin dil politikasını belirleyecek bir kurulun mutlaka oluşturulması gerekmektedir.

- Kitle iletişim araçlarında Türkçenin kullanımında özenli davranılmasında ve çocukların dili doğru, güzel ve etkili kullanmalarında ailelerin sorumlu davranmasının gerekli olduğu düşünülmektedir.

- İyi bir dil öğretimi için öğretmenlerin eğitimine ağırlık verilmelidir. Tüm branş ve sınıf öğretmenleri öğrencilere mutlaka Türk dili sevgisi ve bilinci aşılamalıdır. Nitelikli Türkçe öğretmeni yetiştirilmesi ve tüm branş öğretmenlerinin ölçünlü Türkçeyi özenle kullanmasi konularına önem verilmelidir.

- Araştırmada, eğitim ve dil politikalarında yaşanan değişimlerin Türkçe eğitimine yansıması hakkında Giresun ilinde görev yapan ortaokul Türkçe öğretmenlerinin görüşlerinden faydalanılmıştır. Eğitim ve dil politikalarında yaşanan değişimlerin Türkçe eğitimine yansıması hakkında farklı bölgelerde görev yapan öğretmenlerin görüşlerinden de yararlanılabilir ve karşılaştırmalar yapılabilir. 


\section{KAYNAKÇA}

Açık F. (2013). “Türkçe Bağlamında Osmanlı İmparatorluğu Döneminden Günümüze Dil Politikaları”. Yeni Türkiye Türkçe Özel Saylsı 55 (2013) 819-828.

Adem M. (1997). “Ulusal Eğitim Politikamız Nasıl Olmalıdır?”. Ankara Üniversitesi Sbf Dergisi 52/1 (1997) 51-65.

Alkan C. (1977). "Eğitim Teknolojisi Açısından Türk Eğitim Politikası". Ankara Üniversitesi Eğitim Bilimleri Fakültesi Dergisi 10/1 (1977) 31-47.

Azar A. (2011). “Türkiye'deki Öğretmen Eğitimi Üzerine Bir Söylem: Nitelik Mi, Nicelik Mi?”. Yüksekögretim ve Bilim Dergisi 1/1 (2011) 36-38.

Başaran İ. E. (1999). Ĕgitime Giriş. Ankara 1999.

Boran A. (2000). "Cumhuriyet Döneminde Eğitimde Meydana Gelen Değişmeler”. Erciyes Üniversitesi Sosyal Bilimler Dergisi 9 (2000) 303-312.

Dargut T. \& Çelik G. (2014). "Türkçe Öğretmeni Adaylarının Eğitimde Teknoloji Kullanımına İlişkin Tutum ve Düşünceleri”. Ana Dili Eğitimi Dergisi 2/2 (2014) 28-41.

Deringöl Y. (2007). "Türkiye'de Cumhuriyet Döneminden Günümüze İlköğretim Öğretmenleri Yetiştirilmesinin Tarihsel Boyutu ve Eğitimcilerin Görüşlerinin Değerlendirilmesi Üzerine Bir Araştırma”. Hasan Ali Yücel Eğitim Fakültesi Dergisi 2 (2007) 17-27.

Duman G., Baykan A. K., Köroğlu G. N., Yılmaz S \& Erdoğan M. (2014). “Öğretmen Adaylarının Türkiye'deki Eğitim Reformlarını Takip Etme Durumlarının İncelenmesi”. Kuram ve Uygulamada Eğitim Bilimleri 14/2 (2014) 609-628.

Durukan E. (2013). "Dil Politikaları Bağlamında Ab ve Türkiye'de Türkçenin Sorunları". Yeni Türkiye Türkçe Özel Saylsı 55 (2013) 1221-1228.

Ekiz D. (2003). Eğitimde Araştırma Yöntem ve Metotlarına Giriş: Nitel, Nicel ve Eleştirel Kuram Metodolojileri. Ankara 2003.

Fidan N. \& Erden, M. (1987²). Eğitim Bilimine Giriş. Ankara 1987.

Fidan N. K. (2008). “İlköğretimde Araç Gereç Kullanımına İlişkin Öğretmen Görüşleri”. Kuramsal Ĕgitimbilim 1/1 (2008) 48-61.

Göçer A. (2014). "Öğretmen Adaylarının Türkçenin Kullanımına İlişkin Görüşleri: Fenomenolojik Bir Analiz”. Millî Eğitim 43/203 (2014) 23-36.

Gülbahar G. (2006). Cumhuriyet Dönemi (1920-1950) Türk Eğitim Sisteminin Felsefi Temelleri. Yüksek Lisans Tezi. Kırıkkale Üniversitesi, Sosyal Bilimler Enstitüsü, Kırıkkale 2006.

Gülcü A., Solak M., Aydın S. \& Koçak Ö. (2013). "İlköğretimde Görev Yapan Branş Öğretmenlerinin Eğitimde Teknoloji Kullanımına İlişkin Görüşleri”. Turkish Studies 8/6 (2013) 195-213.

Güven A. Z. (2011). “İlköğretim II. Kademe Türkçe Dersi Öğretim Programına İlişkin Öğretmen Görüşleri”. Buca Eğitim Fakültesi Dergisi 29 (2011) 121-133.

İmer K. (2001). Türkiye'de Dil Planlamasl: Türk Dil Devrimi. Ankara 2001.

Karacaoğlu Ö. C. \& Acar E. (2010). "Yenilenen Programların Uygulanmasında Öğretmenlerin Karşılaştığı Sorunlar”. Yüzüncü Yll Üniversitesi Eğitim Fakültesi Dergisi VII/1 (2010) 45-58.

Kartal S. (2013). "Öğretmen Adaylarının Görüşlerine Göre Eğitim Sistemimizde Değiştirilmesi Gereken Noktalar”. Uşak Üniversitesi Sosyal Bilimler Dergisi Özel Sayı (2013) 248-262.

Katrancı, M. \& Uygun, M. (2013). "Sınıf Öğretmenlerinin Türkçe Derslerinde Teknoloji Kullanımına Yönelik Görüşleri”. Adiyaman Üniversitesi Sosyal Bilimler Enstitüsü Dergisi Türkçenin Eğitimi Öğretimi Özel Saylsl, 6(11), 773-797.

Kaygısız İ. (1997). "Eğitim Felsefesi ve Türk Eğitim Sisteminin Felsefi Temelleri”. Eğitim ve Yaşam (1997) 5-15.

Kılıçoğlu M. (2009). 2005 Türkçe Ders Programının Öğretmen Görüşlerine Göre Değerlendirilmesi: Trabzon İli Örneği. Yüksek Lisans Tezi. Karadeniz Teknik Üniversitesi, Sosyal Bilimler Enstitüsü, Trabzon 2009.

Kırmızı F. S. \& Akkaya N. (2009). "Türkçe Öğretimi Programında Yaşanan Sorunlara İlişkin Öğretmen 
Görüşleri”. Pamukkale Üniversitesi Eğitim Fakültesi Dergisi 1/25 (2009) 42-54.

Kösterelioğlu İ. \& Bayar A. (2014). "Türk Eğitim Sisteminin Sorunlarına İlişkin Güncel Bir Değerlendirme". The Journal of Academic Social Science Studies 25/I (2014) 177-187.

MEB (1998). Milli Eğitim Şûraları (1939-1996). Ankara 1998.

Memduhoğlu H. B. (2008). "Türk Eğitim Sisteminin Genel Yapısı”. Eds. H. B. Memduhoğlu \& K. Y1lmaz, Türk Eğitim Sistemi ve Okul Yönetimi (2008). Ankara.

Özdem G. (2007). Türkiye'de 1980 Sonrası Uygulanan Eğitim Politikalarının İlköğretim Okullarında Yarattığ Dönüs̆ümün Değerlendirilmesi (Ankara İli Örneği). Doktora Tezi. Ankara Üniversitesi, Eğitim Bilimleri Enstitüsü, Ankara 2007.

Özpolat A. (2005). “Öğretmenlik Mesleğindeki Değişmelerin Tarihsel-Toplumsal Bağlamı”. Millî Eğitim Dergisi (2005) 166.

Sarı Ö. \& Önkal G. (2007). "Eleştirel Düşüncede Entegrasyon Süreci Olarak Eğitim”. Gaziantep Üniversitesi Sosyal Bilimler Dergisi 6/1 (2007) 45-52.

Şişman M. (2012). Eğitim Bilimine Giriş. Ankara 2012.

Üstüner M. (2004). "Geçmişten Günümüze Türk Eğitim Sisteminde Öğretmen Yetiştirme ve Günümüz Sorunları". İönü̈ Üniversitesi Eğitim Fakültesi Dergisi 5/7 (2004).

Varış F. (Ed.) (1994). Eğitim Bilimine Giriş. Ankara 1994.

Virtanen Ö. E. (2003). "Dil Politikalarının Milliyetçilik Hareketlerindeki Tarihsel Kökenleri”. Haz. E. Uzpeder, Avrupa Birliği Sürecinde Dil Haklart (2003). İstanbul.

Virtanen Ö. E. (2006). "AB İle İlişkiler Çerçevesinde Türkiye'de Dil Politikaları. Der. A. Menz \& C. Schroeder". Türkiye'de Dil Tartışmaları (2006). İstanbul.

Yapıcı M. (2006). "Eğitim Politikaları ve Etkileri". Üniversite ve Toplum Dergisi 6/2 (2006).

Yıldııım A. \& Şimşek H. (2006). Sosyal Bilimlerde Nitel Araştırma Yöntemleri. Ankara 2006.

Yılmaz K. \& Altınkurt Y. (2011). "Öğretmen Adaylarının Türk Eğitim Sisteminin Sorunlarına İlişkin Görüşleri”. Uluslararası İnsan Bilimleri Dergisi 8/1 (2011) 942-973. 